\begin{tabular}{c} 
Journal of Nat. \&App. Sci. \\
\hline OKMANIYE
\end{tabular}

\title{
Yeni Doğan Buzağıların Beslenmesinde Ağız Sütünün Önemi
}

\author{
Fülya SERT ${ }^{*}$, İslim POLAT AÇIK ${ }^{2}$ \\ ${ }^{1}$ Doğu Akdeniz Tarımsal Araştırma Enstitüsü Müdürlüğü, Adana, Türkiye \\ ${ }^{2}$ Çukurova Üniversitesi, Ziraat Fakültesi, Zootekni Bölümü, Adana, Türkiye
}

${ }^{1}$ https://orcid.org/0000-0003-2494-5415

${ }^{2}$ https://orcid.org/0000-0001-6587-2828

*Sorumlu yazar: fulyakurec@gmail.com

\begin{tabular}{|c|c|}
\hline Derleme & ÖZET \\
\hline $\begin{array}{l}\text { Makale Tarihçesi: } \\
\text { Geliş tarihi: } 20 \text { Nisan } 2020 \\
\text { Kabul tarihi: } 8 \text { Eylül } 2020 \\
\text { Online Yayınlanma: } 15 \text { Aralık } 2020\end{array}$ & $\begin{array}{l}\text { Ülkemizde her gün binlerce buzağı doğmakta ancak önemli bir kısmı bakım ve } \\
\text { besleme koşullarının yetersizliği nedeni ile ölmekte ya da verimsiz kalmaktadır. } \\
\text { Sığır işletmelerinin gelirlerinin yaklaşık \% } 40 \text { kadar kısmını buzağıdan, geri kalan } \\
\text { kısmını ise sütten elde edildiği kabul edilmektedir. Bir sığırcılık işletmesinin karlı } \\
\text { olabilmesi için yılda inek başına } 1 \text { yavru alınması hedeflenmektedir. Sığırcılık }\end{array}$ \\
\hline $\begin{array}{l}\text { Anahtar Kelimeler: } \\
\text { Buzağı } \\
\text { Ağız sütü } \\
\text { Besleme } \\
\text { Kalite } \\
\text { Program }\end{array}$ & $\begin{array}{l}\text { işletmelerinde yeni doğan buzağılar, yaşamlarının ilk zamanlarında çok hassas bir } \\
\text { döneme sahiptirler. Doğumdan sonra buzağı için ilk ve en önemli besin gıda ağız } \\
\text { sütüdür (kolostrum). Ağı sütünün içerdiği zengin besin maddeleri, vitaminler ve } \\
\text { mineraller sayesinde buzağının yaşamının ilk günlerinde ihtiyaç duyduğu } \\
\text { bağışılık siteminin güçlü olmasını sağlamaktadır. Bundan dolayı sığır } \\
\text { işletmelerinde yeni doğan buzağılar, ileride sürünün devamlı̆ ğını } \\
\text { sağlayacaklarından buzağı evresindeki bakım ve beslenmesine çok dikkat } \\
\text { edilmelidir. }\end{array}$ \\
\hline
\end{tabular}

\section{The Importance of Colostrum in Nutrition of New Born Calves}

\section{Review}

\section{Article History}

Received: 20 April 2020

Accepted: 8 September 2020

Published online:15 December 2020

\section{Keywords:}

Calf

Colostrum

Feeding

Quality

Program

\begin{abstract}
Thousands of calves are born every day in our country, but a significant part of them die or remain inefficient due to insufficient care and feeding conditions It is accepted that approximately $40 \%$ of the cattle farms' income is derived from calf and the rest from milk.In order for a cattle breeding business to be profitable, it is aimed to take 1 calf per cow per year. New born calves in cattle farms have a very sensitive period in the early days of their lives. The first and most important nutrient-food for calf after birth is colostrum. Thanks to the rich nutrients, vitamins and minerals contained in the colostrum it ensures the strength of the immune system that the calf needs in the first days of its life. Therefore, care should be taken in the care and feeding of the newborn calves at the calf stage, as they will ensure the continuity of the herd in the future.
\end{abstract}

To Cite: Sert F., Açık İP. Yeni Doğan Buzağıların Beslenmesinde Ağız Sütünün Önemi. Osmaniye Korkut Ata Üniversitesi Fen Bilimleri Enstitüsü Dergisi 2020; 3(2): 193-198. 


\section{Giriş}

Sığırcılık işletmelerinin karlılı̆̆g sadece buzağ kayıplarıyla ölçülmemelidir. Yeni doğan buzağıya iyi bir bakım besleme yapılması ileride süt ve döl veriminin istenilen seviyeye getirilmesine neden olacaktır. Sığırcılık işletmelerinde yeni doğan buzağılar, ilk doğdukları dönemde çok hassaslardır [1]. Bu dönemde sürü idaresi önemli bir yer teşkil etmektedir. Yeni doğmuş olan bir buzağının bağışıklık sistemi ve hastalıklara karşı korunması için bazı faktörlere dikkat edilmesi gerekir. Bunların başlıcaları, bulunduğu çevrenin temizliği, sicaklığ 1 , nemi, farklı bir yerde tutulması ve altlıklarının temiz ve bakımlı olması, yeterli ve kaliteli ağız sütü ile beslenmesidir. Yeni doğan buzağının bağışıklık sisteminin gelişmemiş olması, hastalığa yakalanma riskini arttırmakta ve buna bağlı olarak yüksek ölüm oranları bu dönemde görülmektedir [2].

Buzağıların sağlıklı büyümesi sağlıklı beslenmelerine bağlidır. Doğumdan sonra buzağı için ilk ve en değerli besin ağız sütüdür (kolostrum). Ağız sütünün besleyici değeri çok yüksektir ve ayrıca ananın hastalıklara karşı geliştirdiği bağışıklığı buzağıya taşıdığ bilinmektedir. Ağız sütünün içerdiği zengin besin maddeleri, vitaminler ve mineraller buzağının bağışıklık sisteminin güçlü olmasını sağlamaktadır [2]. Buzağıların ağız sütünden sonraki beslemesi doğum ağırlığının onda biri kadar tam yağlı süt ya da süt ikame yemi ile yapılmalı, ikinci haftadan sonra buzağının önüne azar azar sindirilebilirliği yüksek ve kaliteli buzağı başlangıç yemi verilmelidir.

Buzağıların beslenmesi sürünün döl verimini, et ve süt verimini doğrudan etkileyen en önemli faktörlerden biridir. Bundan dolayı sığır işletmelerinde yeni doğan buzağılar, ileride sürüyü temsil edecekleri için buzağı evresindeki bakım ve beslemeye çok dikkat edilmelidir. Buzağı büyütmede temel amaç, buzağı kayıplarını en aza indirerek sağlıklı ve iyi gelişmiş buzağılar yetiştirmek ve sürünün devamlılığını sağlamaktır.

\section{Doğum Gerçekleştikten Sonraki Bakım}

Doğum olduktan sonra ilk olarak buzağının ağız ve burun boşluklarındaki doğum artıkları temizlenmelidir. Sağlıkı bir buzağı, doğumdan sonra yaklaşık yarım saat içinde ayağa kalkmaktadır. Bu sırada ananın yavruyu yalaması sağlanmalıdır. Bu olmadığı takdirde, yavru temiz bir havlu ile kurulanmalı ve sonuç olarak buzağının 1sınması sağlanmalıdır. Buzağının göbek kordonu 8-10 $\mathrm{cm}$ mesafeden kesilmeli ve bağlanmalı, tentürdiyotla dezenfekte edilmelidir.

\section{Ağız Sütü (Kolostrum)}

Doğumdan sonra salgılanan ilk süte ağız sütü (kolostrum) denir ve buzağı için ilk ve en değerli besin maddesidir. Normal sütten renk ve içerik açısından belirgin derecede farklı bir sıvıdır. Ağız sütünün salgılanması meme bezinde doğuma yaklaşık beş hafta kala başlamakta, gebeliğin son iki haftasında en üst seviyeye ulaşmakta, doğumla birlikte de durmaktadır [3].

Yeni doğanların kolostrumdaki antikorlardan yeterince yararlanabilmeleri için, hem kolostrumun gamma immunoglobulin (IgG) bakımından daha zengin olduğu ve doğumdan sonra ilk 12-24 saate kadar uzayan sürede kolostrum almaları önem taşımaktadır. Intestinal absorbsiyonun doğumdan sonraki ilk 6 saat içinde maksimum seviyeye ulaşmakta sonra ise hızla düşmektedir $[4,5]$.

Buzağıların beslenmesinde kolostrum kalitesi, kolostrumdaki IgG miktarı ile belirlenir. Her sağımda, ilk sağımda alınan kolostruma göre IgG miktarı azalmasına bağlı olarak IgG'lerin koruyucu etkisi giderek azalmaktadır [6].

Ağız sütü normal süte göre farklı olup kuru madde bakımından 2 kat, protein bakımından 5 kat ve mineral madde bakımından ise 3 kat oranda normal süte göre yüksek içeriğe sahiptir [7]. Aynı zamanda buzağı için gerekli olan enerji, vitamin, hormon, büyüme faktörleri ve hastalıklardan korunmasına yardımcı olabilen bağışıklık maddelerine ( $\operatorname{IgG})$ sahiptir.

Yapılan çalışmalarda, doğumdan sonraki buzağı ölümlerinin yaklaşı \%31'inin yetersiz kolostrum alımına bağlı olarak pasif bağışıklık eksikliğinden kaynaklandığı bildirilmiştir $[7,8]$. Buzağ 1 ölümlerinin birçoğu hayatın ilk dönemlerinde yani henüz bağışıklık buzağıyı koruyacak düzeye ulaşmadan meydana gelmektedir. Aktif bağışıklık ancak 5. haftadan itibaren pasif bağgşıklığın önüne geçebilmektedir. Hayatlarının ilk dönemlerinde buzağıların yeterli pasif bağışıklığa sahip olmaları için serum Ig düzeyinin minimum $10 \mathrm{mg} / \mathrm{mL}$ olmas1 gerekmektedir. 24-48 saat yaşta buzağılar $10 \mathrm{mg} / \mathrm{mL}$ 'nin altında serum Ig düzeyine sahip ise bu buzağıların yeterince pasif bağışıklığa sahip olmayacağ1 belirtilmiştir [8, 9]. 2177 buzağ 1 üzerinde yapılan bir çalışmada \%41'nin yeterli pasif bağışıklığa sahip olamadığı belirtilip, ağız 
sütünün ne kadar önemli olduğu ortaya konmuştur $[8,9]$.

Buzağ1 doğduktan sonra ilk üç gün anasının sütü ile yani kolostrum ile beslenmeli ya da bunu izleyen geçiş sütü (normal süt ile kolostrum arasında zaman ilerledikçe normal süte dönüşen süt) 3-4 ögüun şeklinde günlük 3,5-4 litre verilmelidir. Ananın verdiği fazla kolostrum dondurularak veya ekşitilerek saklanıp ileride başka buzağılara da içirilebilir. Soğuk süt ishal yapabileceği için, buzağıya içirilecek sütün sıcaklığı $35-38^{\circ} \mathrm{C}$ arasında olmalıdır. Buzağılar buzağı maması ile de beslenebilirler. Buzağı mamas1 kolostrum alımindan hemen sonra da verilebilir ya da 7-10 günlük yaştan sonra da verilebilmektedir.

\section{Buzağı Besleme Programı}

Buzağının doğum ağırlığına göre süt içirme yani beslenme programları hazırlanmalıdır. Toplamda tüketilecek 150-160 kg'lik süt veya yapay sütle 56 haftalık bir besleme programı ile buzağ büyütme yapılabilir. Günlük olarak buzağılara ilk iki hafta doğum ağırlığının \%10'u, 3. hafta \%1012'si oranında süt veya buzağı maması içirilmelidir. Daha sonraki haftalarda bu oran kademeli olarak \%10 ve \%8'e düşürülerek buzağ1 sütten kesilmelidir. Günlük süt, sabah ve akşam iki öğün halinde içirilmelidir. Normal süt ve kolostrumdaki besin madde içerikleri arasında önemli farklılıklar bulunmaktadır (Tablo 1). Süt ve kolostrum bileşimi içeriği türlere göre farklılık göstermektedir (Tablo 2). Buzağılar için doğum ağırlığı esasına göre hazırlanan 5 haftalık bir sütle besleme programı aşağıdaki Tablo 3 'de verilmiştir [10].

Kolostrumun anneden sağılarak kova veya biberonla buzağıya verilmesi buzağının doğumdan sonra annesinden beslenme süresi ve miktarının hesaplanmasında kolaylık sağlamaktadır [12].

Tablo 1. Kolostrum ve normal sütün besin madde kompozisyonu, \% [13]

\begin{tabular}{cccccccc}
\hline İçerik & $\begin{array}{c}\text { Kuru } \\
\text { madde (\%) }\end{array}$ & Yağ (\%) & $\begin{array}{c}\text { Yağs1z KM } \\
(\boldsymbol{\%})\end{array}$ & $\begin{array}{c}\text { Toplam } \\
\text { Protein } \\
(\boldsymbol{\%})\end{array}$ & $\begin{array}{c}\text { Laktoz } \\
(\boldsymbol{\%})\end{array}$ & $\begin{array}{c}\text { Mineral } \\
(\boldsymbol{\%})\end{array}$ & Ig (\%) \\
\hline Kolostrum & 23,9 & 6,7 & 16,7 & 14,0 & 3,3 & 1,03 & 6,0 \\
Normal Süt & 12,6 & 3,6 & 9,6 & 3,2 & 5,0 & 0,74 & 0,09 \\
\hline
\end{tabular}

Tablo 2. Farklı türlere ait sütlerin ve kolostrumlarının bileşimi [11]

\begin{tabular}{ccccccccc}
\hline İçerik & \multicolumn{4}{c}{ Kolostrum (\%) } & \multicolumn{5}{c}{ Süt (\%) } \\
\hline & Sı̆̆ır & Koyun & Keçi & Domuz & Sı̆̆ır & Koyun & Keçi & Domuz \\
\hline Su & 77,5 & 58,8 & 81,0 & 69,8 & 87,5 & 83,7 & 88,0 & 80,1 \\
Yăg & 3,6 & 17,7 & 8,2 & 7,0 & 3,5 & 5,3 & 3,5 & 8,2 \\
Laktoz & 3,1 & 2,2 & 3,4 & 2,4 & 4,6 & 4,6 & 4,6 & 4,8 \\
Protein & 14,3 & 20,1 & 5,7 & 18,8 & 3,3 & 5,5 & 3,1 & 5,8 \\
Kül & 1,5 & 1,0 & 0,9 & 0,6 & 0,8 & 0,9 & 0,79 & 0,63 \\
\hline
\end{tabular}

Tablo 3. Buzağı besleme programı [10]

\begin{tabular}{ccccccc}
\hline \multirow{2}{*}{$\begin{array}{c}\text { Buzağı } \\
\text { doğum ă̆ırlığı (kg) }\end{array}$} & \multicolumn{5}{c}{ Haftalar ve içirilecek süt miktarı (lt) } \\
\cline { 2 - 7 } & 1. hafta & 2. hafta & 3. hafta & 4. hafta & 5. hafta & Toplam \\
\hline $\mathbf{2 5 - 2 9}$ & 2,5 & 3 & 3 & 2 & 1,5 & 84 \\
$\mathbf{3 0 - 3 4}$ & 3 & 3 & 3,5 & 3 & 2 & 101,5 \\
$\mathbf{3 5 - 3 9}$ & 3,5 & 4 & 4 & 3,5 & 2 & 119,0 \\
$\mathbf{4 0 - 4 4}$ & 4 & 4,5 & 5 & 3,5 & 2 & 133,0 \\
$\mathbf{4 5 - 4 9}$ & 4 & 5 & 5,5 & 4 & 3 & 150,5 \\
$\mathbf{5 0}$ ve üzeri & 5 & 5,5 & 6 & 4 & 3 & 164,5 \\
\hline
\end{tabular}




\section{Ağız Sütü (Kolostrum) Kalitesine Etki eden Faktörler}

Buzağıların sağlıklı, büyüme ve gelişmeleri için, buzağılar doğar doğmaz en kısa sürede kaliteli kolostrum verilmelidir [14]. Kolostrum miktarını ve kalitesini etkileyen mevsime bağlı sicaklık, ortamın sıcaklığı, 1şık ayarı ve beslenme şekli gibi birçok etken bulunmaktadır. Hayvanın strese maruz kalması hayvanın refahını etkilemekte olup; ananın 45 günden az ya da 70 günden fazla kuruda kalması buna bağlı olarak beslemesini de etkilemektedir. Ananın gebeliğin son zamanlarında mevsime bağlı olarak sicaklık stresine bağlı kalması sonucu IgG seviyesinde bir düşüş meydana gelmektedir [15]. Yine ananın karanlık, havasız, kirli ortamda bulunması, yetersiz veya dengesiz beslenmesi (eksik vitamin, mineral vb.) ve mastitis kolostrum içerisindeki IgG yoğunluğunu düşürmekte, miktarını azaltmakta ve buzağının iyi kalitede ve miktarda ağız sütü almasını olumsuz etkilemektedir [15]. Kolostrum kalitesini etkileyen başka bir faktör de ananın yaşıdır [16]. İleri yaştaki inekler sürüde daha fazla patojenlere maruz kaldıkları ve bu durum sonucu çok sayıda koruyucu antikor geliştirdiklerinden dolayı ileri yaştaki ineklerde Ig konsantrasyonu, ilkine doğum yapan ineklerden daha yüksektir [17].

Her sağımda, ilk sağımda alınan kolostruma göre IgG miktarı azalmasına bağlı olarak Ig'lerin koruyucu etkisi giderek azalmaktadır [6]. Kolostrumun; krema kivamında koyu ve besleyici özellikte olması, IgG içeriğine (en az $50 \mathrm{~g} / \mathrm{L}$ ) bakılmas1, doğum öncesi memede sizınt1 ve yara olmaması, kuru dönemde aşıları tamamlanmış ve mastitis tüberküloz ve brusella gibi hastalıklardan korunmuş olması kaliteli olduğunu göstermektedir [18].

Yapılan bir çalışmada kuru dönemde kolostrum üretiminin yetersiz besleme sonucu azaldı $\breve{g}_{1}$ bildirilmiştir [19]. Kuru dönemdeki beslemenin kolostrum kalitesini etkilemesi ile ilgili çalışmalara da rastlanılmıştır [20]. Valenta ve Zilkova [21] tarafindan yapılan bir çalışmada kuruda kalma süresinin kolostrum kalitesini etkilediği belirtilmiştir.

Kuruda kalma süresinin kısa olması sonucu ağız sütünde bulunan antikor miktarının azaldığ [22], ağız sütü kalitesinin etkilenmediği ancak miktarında azalış olduğu yapılan bir çalışmada ifade edilmiştir [23]. İyi kaliteli ağız sütünün IgG içeriğinin $50 \mathrm{~g} / \mathrm{L}$ 'in üzerinde olması gerektiği bilinmektedir $[8,24]$. Buna bağlı olarak yapılan birçok çalışmada ağız sütünün IgG içeriğinin çok değişkenlik gösterdiği, bir çalışmada Siyah alaca 1rkı ineklerde IgG içeriğinin 9 ile $186 \mathrm{~g} / \mathrm{L}$ arasında değiştiği bildirilmiştir $[8,25]$. Kanda istenilen Ig düzeyinin elde edilmesi için buzağıya verilmiş olan kolostrumun kalitesi, miktarı ve kolostrumun emilim düzeyleriyle ilişkili olduğu bilinmektedir $[8,26]$.

Irklara göre ağız sütünün kalitesi farklılık göstermektedir. Jersey irkında antikor seviyesi en yüksek, Siyah Alaca 1rkında antikor düzeyi en düşüktür [27]. Yine yapılan başka çalışmada Siyah Alaca 1rk1 ineklerin kolostrumunun Jersey ve İsviçre Esmeri ineklerin kolostrumundan daha kaliteli olduğu, Jersey ve Siyah Alaca 1rk1 ineklerin ağız sütünün Esmer ve Ayrshire 1rk1 ineklerin ağız sütünden daha düşük kaliteli olduğu bildirilmiştir [28, 29].

Doğumu takip eden ilk 3-6 saat içerisinde buzağının yeterli bağlı IgG alması gerektiği bildirilerek, $\quad 90 \mathrm{mg} / \mathrm{mL}$ 'den fazla bağışıklık proteini içeren ağız sütünün kaliteli olduğu, iyi kalitede bir ağız sütünün $\quad 65-100 \quad \mathrm{mg} / \mathrm{mL}$ bağışıklık proteini içermesi gerektiği, 40-65 $\mathrm{mg} / \mathrm{mL}$ bağışıklık proteini içerenlerin orta kalitede, $40 \mathrm{mg} / \mathrm{mL}$ 'den daha az bağışıklık proteini içerenlerin ise kötü kalitede ağız sütü olduğu bildirilmiştir [30, 31, 32]. Sütün oluşumu sırasinda serum IgG konsantrasyonuna kandan geçen immunoglobülinlerin neden olduğu bildirilmektedir [33, 34].

\section{Sonuç}

Buzağılara hayatlarının ilk zamanlarında verilen ağız sütünün kalitesi ve miktarının iyi olması buzağıların ilerleyen dönemlerinde sağlıklı olmalarını ve hayatta kalmalarını etkilemektedir. Eğer ağız sütü verilmesi iyi yönetilmezse sürüde ciddi kayiplar meydana gelebilmektedir. Her alanda olduğu gibi hayvancılık işletmelerinde amaç para kazanmak ve kar elde etmek olduğundan, işletmelerde sürünün devamlılığı için sağlıklı buzağılar yetiştirilmelidir. Bundan dolayı sığır işletmelerinde yeni doğan buzağılar, ileride sürüyü temsil edecekleri için buzağı evresindeki bakım ve beslemeye çok dikkat edilmelidir.

\section{Kaynakça}

[1] Ünlü HB., Erkek R., Mert S., Özdoğan M. Buzağı beslemede doğal yem katkı maddelerinin kullanımı, Hayvansal Üretim 2013; 54(2): 36-42. 
[2] Heinrichs AJ., Jones C. Feeding the new born dair calf, The Pennsylvania State University 2003; 328 Boucke Building, University Park. USA: Cat.

[3] Wattiaux AM., Howard TW. Dairy essentials, Babcock Institute for International Dairy Research and Development 1997; USA: WI 53706.

[4] Kahrs RF. Infectious bovine rhinotracheitis: A review and update, J. Am. Vet. Med. Ass 1977; 171, 1055-1064.

[5] Straub OC. Infectious bovine Rhinotracheitis virus. In virus infections of vertebrates, Series Ed. M.C. Horzinek, Vol.3: Virus Infections of Ruminants Ed. Z. Dinter, B. Morein, Elsevier Science Publishers BV,Amsterdam-Oxford-New York-Tokyo 1990; 71-108.

[6] Kirk JH. Colostrum: The key to control of calfhood diseases and death loss, 2003. http://www.vetmed.ucdavis.edu/vetext/INF-DACOLOSTRUM.HTML

[7] Walsh RB., Walton JS., Kelton DF., LeBlanc SJ., Leslie KE., Duffield TF. The effect of subclinical ketosis in early lactation on reproductive performance of postpartum dairy cows, J Dairy Sci 2007; 90, 2788-2796.

[8] Karslı MA., Evci Ş. Buzağı kayıplarının önlenmesinde inek ve buzağ beslemesinin önemi, Lalahan Hay. Araşt. Enst. Dergisi 2018; 58 (Özel Say1): 23-34.

[9] Vicente F., Rodríguez ML., MartínezFernández A., Soldado A., Argamentería A., Peláez M., Roza-Delgado B. Subclinical ketosis on dairy cows in transition period in farms with contrasting butyric acid contents in silages, The Scientific World Journal Article 2014; ID 279614.

[10] Tümer S. Buzağıların Bakım Ve Beslenmesi Ege Tarımsal Araştırma Enstitüsü Müdürlüğü Çiftçi Broşürü No: 87 1998, Menemen-İzmir.

[11] Banerjee GC. A Text book of animal husbandry, 8th. New Delhi: Oxford and IBH Publishing Co. Pvt. Ltd; 2005.
[12] Jasper J., Weary DM. Effects of ad libitum milk intake on dairy calves, Journal of Dairy Science 2002; 85(11): 3054-3058.

[13] Erdem H., Atasever S. Yeni doğan buzağılarda kolostrumun önemi, OMÜ Zir. Fak. Dergisi 2005; 20(2): 79-84.

[14] Blätter U., Hammon HM., Morel C., Philipona C., Rauprich A., Rome V., Le HuërouLuron Le I., Guilloteau P., Blum JW. Feeding colostrum, its composition and feeden duration variably modify proliferation and morphology of the intestine and digestive enzyme activities of neonatal calves, Journal of Nutrition 2001; 131, 1256-1263.

[15] Tarım ve Orman Bakanlığı. Büyükbaş Hayvancilik (Siğırcilı) https://www.tarimorman.gov.tr/HAYGEM/Belgel er/Hayvanc\%C4\%B $11 \%$ C4\%B1k/B\%C3\%BCy\% $\mathrm{C} 3 \% \mathrm{BCkba} \% \mathrm{C} 5 \% 9 \mathrm{~F} \% 20$ Hayvanc\%C4\%B11\%C $4 \% \mathrm{~B} 1 \mathrm{k} / 2017 \% 20 \mathrm{Y} \% \mathrm{C} 4 \% \mathrm{~B} 11 \% \mathrm{C} 4 \% \mathrm{~B} 1 / \mathrm{B} \% \mathrm{C} 3 \%$ BCy\%C3\%BCkba\%C5\%9F\%20Hayvan\%20Yeti $\%$ C5\%9Ftiricili\%C4\%9Fi.pdf.

[16] Devery-Pocius JE., Larson BL. Age and previous lactations as factors in the amount of bovine colostral immunoglobulins, J. Dairy Sci 1983; 66, 221.

[17] Koyuncu M., Karaca M. Buzağılarda yaşama gücünün anahtarı "Kolostrum", J. Anim. Prod 2018; 59(1): 67-78.

[18] Hayvancılık/Büyükbaş Hayvanc1lık/2016 Y11//Buzağ1 Bakım ve Beslenmesi.pdfwww.tarimorman.gov.tr

[19] Selk GE. Disease protection for baby calves, 2003; http://osuextra.okstate.edu/pdfs/F3358web.pdf.

[20] Sellers RA. Guide to colostrum and colostrum management for dairy calves, 2001; http://www.aphis.usda. gov /vs/ceah/ncahs/nahms/dairy/bamn/BAMN Colostrum.pdf

[21] Valenta J., Zilkova JA. Practical method of grading, preservation and use of colostrum for calves in the first day of life, Veterinarstvi 1988; 38(6): 276-279.

[22] Brinton AH., Whitlow LW. Feeding dairy heifers from birth to weaning, 2005; 
http://www.cals.ncsu.edu/an_sci/ extension /dairy/202D.pdf

[23] Grusenmeyer DJ., Ryan CM., Galton DM., Overton TR. Shortening the dry period from 60 to 40 days does not affect colostrum quality but decreases colostrum yield by Holstein cows, Journal of Animal Science 2006; 84 (Suppl, 1): 336.

[24] Mandebvu P., Ballard CS., Sniffen CJ., Tsang DS., Valdez F., Miyoshi S., Schlatter L. Effect of feeding an energy supplement prepartum and postpartum on milk yield and composition, and incidence of ketosis in dairy cows, Animal Feed Science and Technology 2003; 105, 81-93.

[25] Stokol T., Nydam DV. Effect of hemolysis on nonesterified fatty acid and betahydroxybutyrate concentrations in bovine blood, $\mathrm{J}$ Vet Diagn Invest 2006; 18(5): 466-469.

[26] Gillund P., Reksen O., Gröhn YT., Karlberg K. Body condition related to ketosis and reproductive performance in Norwegian dairy cows, J Dairy Sci 2001; 84, 1390-1396.

[27] Heinrichs J. Measuring colostrum quality, Dairy Digest, April 2000; http://ww.das.psu.edu/XDairy.cfm

[28] Shearer J., Mohammed HO., Brenneman JS., Tran TQ. Factors associated with concentrations of 1mmunoglobulins in colostrum at the first milking post-calving, Pre.Vet. Med. 1992; 14(1-2): 143-154.

[29] Morin DE., Constable PD., Maunsell FP. McCoy GC. Factors associated with colostral specific gravity in dairy cows, J. Dairy Sci. 2001; 84(4): 937-943.

[30] Moran J. Calf rearing: A practical guide. Second edition. Collingwood, Vic, 3066, Australia: Landlinks Press, 150 Oxford Street (PO Box 1139); 2005.

[31] Indra E., Daina K., Jel̦ena Z. Analysis of factors influencing immunoglobulin concentration in colostrum of dairy cows, Lucrări Ştiinţifice Seria Zootehnie 2012; 57, 256-259.

[32] Hoyraz M., Sezer R., Demirtaş M., Koç A. Siyah-alaca ineklerin ağız sütü kalitesi ve içeriği üzerine bir araştırma, Tralleis Elektronik Dergisi 2015; 4, 1-7.
[33] Murphy BM., Drennan MJ., O’Mara FP., Earley B. Cow serum and colostrum immunoglobulin (IgG1) concentration of five suckler cow breed types and subsequent immune status of their calves, Irish Journal of Agricultural and Food Research 2005; 44, 205-213.

[34] Göncü S., Mevliyaoğulları E., Koluman N. Siyah Alaca inek ve düvelerde kolostrum kalitesi ve buzağıların bağışıklık düzeyleri, Ç.Ü.Z.F. Dergisi 2013; 28(1): 31-38. 